\title{
PENGARUH PIJAT BAYI TERHADAP DURASI MENYUSU
}

\section{NIKMAH JALILAH RITONGA ${ }^{1}$, HANI AMALIAH MAJIDAH ${ }^{2}$, RIRIS SITORUS ${ }^{3}$, DIAH EVAWANNA ANUHGERA ${ }^{4}$, KARDINA HAYATI ${ }^{5}$, ANITA SRI GANDARIA PURBA ${ }^{6}$}

\author{
1,2,3,4,5,6 INSTITUT KESEHATAN MEDISTRA LUBUK PAKAM \\ Jl.Sudirman No.38 Lubuk Pakam \\ E-mail : ritonganikmah@yahoo.com
}

DOI : $10.35451 / j k k . v 3 i 1.490$

\begin{abstract}
The duration of nursing a baby varies according to the baby's suction pattern. If breastfeeding lasts too long (more than half an hour) or too short (less than 4 minutes), this indicates the possibility of problems with attachment between the baby and the mother's nipples. The frequency of breastfeeding in infants will greatly affect the physical and emotional health of the baby, which with the frequency and duration of breastfeeding will increase the calm condition of the baby and the baby's weight will increase. Efforts to offer to improve the condition of calm and weight of the baby one of which is infant massage. The purpose of this study was to determine the effect of infant massage on the duration of breastfeeding in infants. The design of the study is Quasi-Experiment with one group pre and post test design. Taking this sample with purposive sampling technique. The number of samples is 10 respondents. From the results of the bivariate test analysis using the paired simple $t$ test, a significant value is obtained ( $p$ value: 0.000 ), so that $p<0.005$, it can be concluded that there is an effect of infant massage on the duration of breastfeeding in infants. Therefore, it is expected that health workers apply baby massage as a method to increase the duration of breastfeeding.
\end{abstract}

Keywords: baby massage, breastfeeding duration

\section{PENDAhUlUAN}

Menyusui merupakan proses fisiologis untuk memberikan nutrisi pada bayi secara optimal IDAI (2010). Pemberian Air Susu Ibu (ASI) Eksklusif pada bayi sejak dilahirkan selama enam bulan, tanpa menambahkan dan/atau mengganti dengan makanan atau minuman lain. Menurut WHO (2010), ASI eksklusif dapat melindungi bayi dan anak terhadap penyakit berbahaya dan mempererat ikatan kasih sayang (bonding) antara ibu dan anak.

Hasil laporan Global Media Analysis yang dilakukan oleh CARMA International untuk UNICEF. Menunjukkan bahwa isu kurang gizi (undernutrition) mendapat perhatian yang meningkat secara global. Isu menyusui mendapat perhatian yang lebih rendah dibandingkan isu kurang gizi (UNICEF, 2013). Perlu adanya upaya mendorong dalam peningkatan pemberian ASI. Menurut WHO (2017), 
setiap tahun, sekitar 2,6 juta bayi tidak bertahan sampai satu bulan pertama mereka. Laporan UNICEF dirilis bersamaan dengan peluncuran kampanye global dengan motto Every Child Alive. Lebih dari 80 persen kematian bayi yang baru lahir dapat dicegah melalui pemberian ASI Eksklusif selama paling sedikit 6 bulan.

International Baby Food Action Network/ IBFAN (2014). Asia melaporkan hasil asesmen yang menggunakan perangkat The World Breastfeeding Trends Initiative (WBTI). Mengenai implementasi Strategi Global Pemberian Makan pada Bayi dan Anak di 51 negara, termasuk Indonesia. Indonesia menduduki peringkat ke tiga terbawah dari 5 negara yang mengikuti penilaian status kebijakan dan program pemberian makan bayi dan anak.

Menurut Riskesdas (2013), proses mulai menyusui terbanyak terjadi pada 1-6 jam setelah kelahiran $(35,2 \%)$ dan kurang dari 1 jam (inisiasi menyusui dini) sebesar $34,5 \%$. Sedangkan proses mulai menyusui terendah terjadi pada 7-23 jam setelah kelahiran yaitu sebesar 3,7\%. Keputusan Menteri Kesehatan Nomor 28 Tahun 2017 tentang Izin dan Penyelenggaraan praktik bidan menyebutkan bahwa bidan berwenang memantau tumbuh kembang bayi melalui deteksi dini dan stimulasi tumbuh kembang. Salah satu bentuk stimulasi yang selama ini dilakukan adalah dengan pijat bayi.

Manfaat pemberian ASI diantaranya sebagai nutrisi, meningkatkan kecerdasan dan meningkatkan jalinan kasih sayang. Keuntungan menyusui akan meningkat seiring lama menyusu eksklusif selama enam bulan. Menurut Rencana Pembangunan Jangka Menengah Nasional/RPJMN (20152019) yang terkait dengan pemberian ASI eksklusif yaitu Menurunkan Angka Kematian Bayi (AKB) menjadi 24 per 1000 kelahiran.
Pijat bayi merupakan sentuhan setelah kelahiran, serta dapat memberikan jaminan adanya kontak tubuh berkelanjutan yang dapat mempertahankan perasaan nyaman pada bayi. Terapi sentuh, terutama pijat pada bayi dapat menghasilkan perubahan fisiologis yang menguntungkan (Roesli, 2016)

Sebuah penelitian yang dilakukan Field dan Scafidi menunjukkan bahwa 20 bayi premature yang dipijat selama $3 \times 15$ menit setiap hari selama 10 hari mengalami peningkatan per hari 20\%-47\% lebih banyak daripada bayi yang tidak dipijat. Penelitian pada bayi cukup bulan berusia 1-3 bulan yang dipijat selama 6 minggu mengalami kenaikan berat badan yang lebih tinggi dari kelompok bayi yang tidak dipijat.

Pijat bayi mudah dipelajari dengan beberapa kali latihan, disamping murah karena hanya memerlukan minyak/baby oil, juga banyak manfaatnya. Dampak positif dari pijat bayi antara lain: menurunkan kadar hormone stress, peningkatan kadar zat daya tahan tubuh (immunoglobin), memperbaiki sirkulasi darah, merangsang fungsi pencernaan serta pembuangan, meningkatkan nafsu makan, mengubah gelombang otak yang dapat membuat bayi tidur lelap, meningkatkan aliran oksigen dan nutrisi menuju sel, meningkatkan kenaikan berat badan dan mengeratkan ikatan batin antara bayi dengan orang tua (bonding), meningkatkan volume ASI (Fitriani, 2007)

Rentang frekuensi menyusui yang optimal adalah antara 8-12 kali setiap hari. Tetapi sebaiknya menyusui bayi tanpa dijadwal, karena bayi akan menentukan sendiri kebutuhannya. Ibu harus menyusui bayinya jika bayi menangis bukan karena sebab lain atau 
ibu sudah merasa ingin menyusui bayinya.

Melalui tindakan pijat bayi aktivitas Nervus Vagus mempengaruhi mekanisme penyerapan makanan pada bayi yang dipijat sehingga peningkatan tonus nervus vagus akan meningkatkan enzim penyerapan gastrin dan insulin sehingga penyerapan makanan menjadi lebih baik yang akan membantu peningkatan berat badan bayi. Aktivitas Nervus Vagus secara otomatis juga akan meningkatkan volume ASI melalui penyerapan makanan yang baik pada tubuh bayi sehingga bayi cepat lapar dan akan lebih sering menyusu pada ibunya (Kelly, 2008)

Salah satu dari manfaat pijat bayi yang telah disebutkan di atas adalah meningkatkan nafsu makan. Peningkatan nafsu makan ini ditambah dengan peningkatan aktivitas nervus vagus/saraf pengembara (system saraf otak yang bekerja untuk daerah leher ke bawah sampai dada dan rongga, perut) dalam menggerakkan sel peristaltic (sel di saluran pencernaan yang menggerakkan dalam saluran pencernaan. Dengan demikian, bayi cepat lapar atau ingin makan karena pencernaannya semakin lancar
(Subakti, 2008)

\section{METODE}

Penelitian ini menggunakan metode kuantitatif, Rancangan PreEksperime one group pretest posttest design. Lokasi penelitian di klinik Nining Pelawati Lubuk Pakam. Sampel penelitian ini adalah ibu menyusui yang belum pernah melakukan pijat bayi. Teknik pengambilan sampel dengan Non Probability Sampling dengan metode Purposive Sampling.

\section{HASIL}

Tabel 1. Rerata Durasi Menyusu Sebelum dan sesudah Pijat Bayi Pada Bayi

\begin{tabular}{cccc}
\hline $\begin{array}{c}\text { Durasi } \\
\text { Menyusu }\end{array}$ & N & Mean & $\begin{array}{c}\text { Std. } \\
\text { Deviati } \\
\text { on }\end{array}$ \\
\hline Pre Test & 1 & 162 & 45.656 \\
\hline $\begin{array}{c}\text { Post } \\
\text { Test }\end{array}$ & 1 & 219 & 56.065 \\
\hline
\end{tabular}

Dari tabel 1 menunjukkan bahwa rerata durasi menyusu sebelum pijat bayi adalah 162 dengan standar deviasi 45.656, sedangkan durasi menyusu setelah pijat bayi adalah 219 dengan standar deviasi 56.065 dari 10 responden yang diteliti.

Tabel 2. Pengaruh Pijat Bayi terhadap Durasi Menyusu Pada Bayi Di Klinik Nining Pelawati Tahun 2020

\begin{tabular}{|c|c|c|c|c|c|}
\hline \multirow{3}{*}{$\begin{array}{c}\text { Durasi } \\
\text { Menyusu }\end{array}$} & \multicolumn{5}{|c|}{ Paired Sample t-Test } \\
\hline & \multirow[t]{2}{*}{ Mean } & \multirow{2}{*}{$\begin{array}{l}\text { Standar } \\
\text { Deviasi }\end{array}$} & \multicolumn{2}{|c|}{$\begin{array}{l}95 \% \text { Interval } \\
\text { Confidence }\end{array}$} & \multirow[t]{2}{*}{$\begin{array}{c}p \\
\text { Value }\end{array}$} \\
\hline & & & Lower & Upper & \\
\hline $\begin{array}{l}\text { Pre Test - } \\
\text { Post test }\end{array}$ & $\begin{array}{c}- \\
43.000\end{array}$ & 46.200 & -76.050 & -2.943 & 0.016 \\
\hline
\end{tabular}

Tabel 2 diatas menunjukkan hasil analisis pengaruh pijat bayi terhadap durasi menyusu pada bayi Di Klinik Nining Pelawati Lubuk Pakam menggunakan uji paired sample t-test dan didapatkan hasil nilai $p$ - value $=$ $0,016<0,05$. Maka dapat disimpulkan ada pengaruh yang signifikan antara sebelum dan sesudah pijat bayi terhadap durasi menyusu pada bayi di klinik Nining Pelawati Tahun 2020. 


\section{PEMBAHASAN}

\subsection{Rerata durasi menyusu sebelum dan sesudah Pijat Bayi.}

Dari tabel 1 dapat dilihat bahwa rerata nilai produksi asi sebelum pijat bayi adalah 162 dengan standar deviasi 45.656.

Hasil penelitian ini sejalan dengan teori yang menyatakan bahwa pijat bayi dapat meningkatkan nafsu makan. Pijat bayi menyebabkan bayi menjadi lebih rileks dan dapat beristirahat dengan efektif sehingga ketika bayi terbangun akan membawa energi cukup untuk beraktivitas. dengan aktivitas yang optimal, bayi menjadi cepat lapar sehingga nafsu makannya meningkat. Peningkatan nafsu makan ini juga ditambah dengan peningkatan aktivitas nervus vagus (system sarat otak yang bekerja untuk daerah leher ke bawah sampai dada dan rongga perut) dalam menggerakkan sel peristaltic untuk mendorong makanan ke saluran pencernaan. Dengan demikian, bayi lebih cepat lapar atau ingin makan karena pencernaannya semakin lancar (Roesli, 2008)

Menurut penelitian Fitriahadi (2016) Pijat bayi adalah metode teknik dalam asuhan kebidanan neonatus, bayi dan balita dengan melakukan massage secara lembut dan berurutan sejak dari wajah sampai ujung kaki, dimana dengan melakukan pemijatan bayi seluruh otot bayi akan relaks, peredaran darah akan menjadi lancar dan tidur bayi akan nyenyak. Selain itu dengan pijat bayi akan meningkatkan frekuensi dan durasi menyusu sehingga bayi akan merasa nyaman dan tenang saat menyusu.

Hasil penelitian ini juga didukung penelitian yang dilakukan Izmi Fadhillah (2018) yang menyatakan bahwa Secara statistic dari hasil uji pengaruh menggunakan uji t didapatakan bahwa ada pengaruh pijat bayi terhadap durasi menyusu bayi, sehingga bidan diharapkan untuk terus memotivasi ibu untuk melakukan pijat bayi agar peningkatan durasi menyusui pada bayinya juga semakin meningkat serta memotivasi pemberian ASI eksklusif.

Menurut asumsi peneliti pijat bayi dapat berpengaruh terhadap durasi menyusu karena manfaat dari pijat bayi selain memberikan kenyamanan pada bayi juga dapat memperlancar peredaran darah dan sistem metabolisme dalam tubuh bayi yang berpengaruh terhadap proses menyusu bayi, sehingga baik semakin sering menyusu kepada ibunya.

\subsection{Pengaruh Pijat Bayi terhadap Durasi Menyusu}

Analisis yang dilakukan untuk menguji pengaruh variabel indpenden terhadap variabel dependen menggunakan uji paired sample t-test dapat disimpulkan bahwa ada pengaruh pijat bayi terhadap durasi menyusu dengan nilai $p$-value $0.016<0.05$.

$\mathrm{Hal}$ ini sejalan juga dengan hasil penelitian Fitriani dan Nurhidayanti yang menyatakan bahwa ada hubungan antara pijat bayi dengan peningkatan nafsu makan. Penelitian Erlian menyatakan bahwa ada pengaruh pijat bayi usia 0-4 bulan terhadap peningkatan frekuensi menyusui. Penelitian Falikhah dan Hidayat menyatakan bahwa terdapat kontrol sebagian besar mengalami peningkatan ratarata frekuensi menyusu $1 x /$ hari yaitu sebanyak $46,7 \quad \% \quad$ (14 responden), 23,3\% (7 responden) mengalami peningkatan $2 x /$ hari, $13,3 \%$ (4 responden) mengalami peningkatan $3 x /$ hari, $16,7 \%$ ( 5 responden) tidak mengalami peningkatan frekuensi menyusu. Hasil uji statistik didapatkan $p$ value 0,000 maka dapat disimpulkan bahwa terdapatperbedaan peningkatan 
frekuensi menyusu pada kelompok perlakuan dan kelompok control.

Menurut asumsi peneliti pijat bayi sangat bermanfaat dalam meningkatkan durasi menyusu karena selain memberikan rasa nyaman, melalui proses pijat bayi sistem pencernaan bayi akan semakin lancer sehingga setelah dilakukan proses pemijatan biasanya bayi akan mudah lapar dan semakin sering menyusu.

\section{KESIMPULAN}

Kesimpulan dalam penelitian ini adalah ada pengaruh pijat bayi terhadap durasi menyusu dengan nilai $p$-value $<0.05$ yaitu 0.016 .

\section{DAFTAR PUSTAKA}

Ashmika Motee, Deerajen Ramasawmy, Prity Pugo-Gunsam. An Assessment of the Breastfeeding Practices and Infant Feeding Pattern among Mothers in Mauritius. 2013. Journal of Nutrition and Metabolism. Volume 2013.

Ayse Gurol and Sevinc Polat, The Effect of Baby Massage on Attachment Between Mother and Ther Infants, 2012. Elsevier, Volume 6 Issue 1 March 2012 Pages 35-41

Badan Perencanaan Pembangunan Nasional (Bappenas). 2014. Rencana Pembangunan Jangka Menengah Nasional (RPJMN) 2015-2019. Jakarta

Erlian E. 2012. Pengaruh pijat bayi terhadap peningkatan frekuensi menyusui dan berat badan bayi di Rumah Sakit Sitti Khadijah 1 Makassar, Skripsi

Falikhah A, Hidayat A. 2015. Pengaruh pijat bayi terhadap frekuensi menyusui pada bayi 0-3 bulan di BPS Dini Melani Condong Catur Sleman Yogyakarta, Naskah Publikasi
Field T, Scafidi \& Schanberg. 1987. Massage of preterm newborns to improve growth \& development. Journal Pediatric Nursing vol 13

Fitriahadi, E. (2016) 'Pengaruh Pijat Bayi terhadap Frekuensi dan Durasi Menyusu Bayi',10(2), pp. 92-97.

Fitriani L, Nurhidayanti N. 2007. Pengaruh pijat bayi terhadap peningkatan nafsu makan pada bayi usia di atas 6 bulan

IDAI. (2010). Buku Ajar HematologiOnkologi Anak. Jakarta : EGC

Izmi Fadilah, 2018. Pengaruh Pijat Bayi terhadap durasi menyusu bayi 030 hari di Klinik Pratama Niar Medan Amplas. Poltekkes Medan

Kemenkes Ri. 2013. Riset Kesehatan Dasar; RISKESDAS. Jakarta: Balitbang Kemenkes Ri

Nancy Mohrbacher, IBCLC \& Kathleen Kendall-Tackett, PhD, IBCLC. Breastfeeding Made Simple: Seven Natural Laws for Nursing Mothers, 2005. New Harbinger Publication, Canada

Roesli U. 2016. Pedoman pijat bayi premature dan bayi usia 0-3 bulan. Jakarta: Niaga swadaya.

Subakti $Y$, Anggraini DR. 2008. Keajaiban pijat bayi dan balita. Jakarta: PT wahyumedia

Tiffany Field. Massage Therapy Research review. 2016. HHS Public Access. Complement Ther Clin Pract. 2016 Aug; 24: 19-31.

UNICEF. 2013. Improving Child Nutrition: The achievable imperative for global.

World Health Organization (2017). Mental disorders fact sheets. World Health Organization. http://www.who.int/mediacentre/ factsheets/fs396/en/ - 